\title{
Dampak Pemahaman Wajib Pajak atas PP Nomor 46 Tahun 2013 Terhadap Penerimaan Pajak Penghasilan Pasal 21 Pada KPP Pratama Kotamobagu
}

\author{
Oleh \\ Speny Ria Manengkey ${ }^{1}$ \\ Sifrid Pangemanan ${ }^{2}$ \\ Winston Pontoh ${ }^{3}$ \\ Fakultas Ekonomi Dan Bisnis \\ Universitas Sam Ratulangi Manado \\ Email: ${ }^{1}$ spenyria@gmail.com
}

\begin{abstract}
Tax is a matter that must be well understood by everyone. Because tax hold an important role in the economy of a country. State revenues from taxation were very helpful all existing development. This research is do in KPP Pratama Kotamobagu and on taxpayer in the region Amurang. The variables used in this study were twu variables, namely understanding the taxpayer on the Government Regulation No. 46 of 2013 (X) and income tax revenue article $21(Y)$. Data collection method used in this study were questionnaires and interviews. Technical analysis of data using simple linear regression analysis. From simple linear regression test result show that understanding the taxprayer on Government Regulation No. 46 of 2013 had a considerable influence on the acceptance of income tax on KPP Pratama Kotamobagu.
\end{abstract}

Keywords : Government Regulation No. 46 of 2013 , Income Tax Revenue

\section{PENDAHULUAN}

Pajak adalah kontribusi wajib kepada negara yang terutang oleh orang pribadi atau badan yang bersifat memaksa berdasarkan Undang-Undang, dengan tidak mendapatkan imbalan secara langsung dan digunakan untuk keperluan negara bagi sebesar-besarnya kemakmuran rakyat. (Mardiasmo 2011:23 ). Pajak merupakan suatu hal yang wajib dimengerti dengan baik oleh semua orang. Karena pajak sangat memegang peranan penting dalam perekonomian suatu negara. Penerimaan negara dari pungutan pajak sangat membantu semua pembangunan yang ada. Meskipun timbal balik yang kita rasakan dari membayar pajak tidak secara langsung kita dapatkan namun dapat kita nikmati lewat semua fasilitas umum yang dibangun dan disediakan oleh pemerintah dari kontribusi pajak yang kita berikan misalnya pembangunan penerangan jalan dll.

Tahun 2013 Direktorat Jenderal (Ditjen) Pajak mengumumkan terbitnya Peraturan Pemerintah Nomor 46 Tahun 2013 (PP No.46/2013) yang menetapkan Pajak Penghasilan (PPh) sebesar 1\% untuk omzet tidak melebihi Rp 4.800.000.000,00 (empat miliar delapan ratus juta rupiah) dalam 1 (satu) tahun pajak terhadap penghasilan dari usaha yang diterima atau diperoleh wajib pajak yang memiliki peredaran bruto yang bersifat final. Pajak Penghasilan yang bersifat final adalah pajak atas penghasilan tertentu dimana mekanisme pemajakannya telah dianggap selesai pada saat dilakukan pemotongan, pemungutan atau penyetoran sendiri oleh Wajib Pajak yang bersangkutan. Dengan memahami aturan pajak ini, diharapkan menjadi langkah awal yang baik untuk menjalani kewajiban perpajakan selanjutnya. dan besar harapan dari pemerintah agar setiap peraturan perpajakan yang dikeluarkan oleh pemerintah bisa dipahami dan diketahui dengan benar oleh semua wajib 
pajak yang ada. Mendasari latar belakang masalah ini maka penulis teratrik untuk mengangkat judul : Dampak Pemahaman Wajib Pajak atas PP No. 46 Tahun 2013 Terhadap Penerimaan Pajak Penghasilan Pasal 21 Pada KPP Pratama Kotamobagu.

Berdasarkan latar belakang masalah penelitian diatas, maka dapat dirumuskan masalah, apakah dampak pemahaman wajib pajak atas PP No. 46 Tahun 2013 terhadap penerimaan pajak penghasilan pasal 21 pada KPP Pratama Kotamobagu, apakah mengalami peningkatan atau penurunan?

Tujuan yang hendak di capai dalam penelitian dan penulisan skripsi ini yaitu untuk mengetahui dampak pemahaman wajib pajak atas PP No. 46 Tahun 2013 terhadap penerimaan pajak penghasilan pasal 21 pada KPP Pratama Kotamobagu.

\section{TINJAUAN PUSTAKA}

Pajak adalah kontribusi wajib kepada negara yang terutang oleh orang pribadi atau badan yang bersifat memaksa berdasarkan Undang-Undang, dengan tidak mendapatkan imbalan secara langsung dan digunakan untuk keperluan negara bagi sebesar-besarnya kemakmuran rakyat. (Mardiasmo 2011:23 )

Menurut Resmi (2010:3) Terdapat dua fungsi pajak, yaitu fungsi budgetair (sumber keuangan negara) dan fungsi regularend (pengatur).

Fungsi Budgetair (Sumber Keuangan Negara)

Pajak merupakan fungsi budgetair, artinya pajak merupakan salah satu sumber penerimaan pemerintah untuk membiayai pengeluaran baik rutin maupun pembangunan. Sebagai sumber keuangan negara, pemerintah berupaya memasukkan uang sebanyak-banyajnya untuk kas negara. Upaya tersebut ditempuh dengan cara ekstensifikasi maupun intensifikasi pemungutan pajak melalui penyempurnaan peraturan berbagai jenis pajak seperti Pajak Penghasilan $(\mathrm{PPh})$, Pajak Pertambahan Nilai (PPN) dan Pajak Penjualan atas Barang Mewah (PPnBM), Pajak Bumi dan Bangunan (PBB), dan lain-lain.

Fungsi Regularend ( Pengatur )

Pajak mempunyai fungsi pengatur, artinya pajak sebagai alat untuk mengatur atau melaksanakan kebijakan pemerintah dalam bidang sosial dan ekonomi, serta mencapai tujuantujuan tertentu di luar bidang keuangan.

Wajib pajak adalah orang pribadi atau badan, meliputi pembayaran pajak, pemotongan pajak, dan pemungutan pajak, yang mempunyai hak dan kewajiban perpajakan sesuai dengan ketentuan peraturan perundang-undangan perpajakan.( Mardiasmo $2011: 23$ )

\section{Peraturan Pemerintah No. 46 Tahun 2013}

Tentang pajak penghasilan atas penghasilan dari usaha yang diterima atau diperoleh wajib pajak yang memiliki peredaran bruto tertentu.

(1) Atas penghasilan dari usaha yang diterima atau diperoleh Wajib Pajak yang memiliki peredaran bruto tertentu, dikenai Pajak Penghasilan yang bersifat final.

(2) Wajib Pajak yang memiliki peredaran bruto tertentu sebagaimana dimaksud pada ayat (1) adalah Wajib Pajak yang memenuhi kriteria sebagai berikut:

1. Wajib Pajak orang pribadi atau Wajib Pajak badan tidak termasuk bentuk usaha tetap; dan

2. Menerima penghasilan dari usaha, tidak termasuk penghasilan dari jasa sehubungan dengan pekerjaan bebas, dengan peredaran bruto tidak melebihi Rp 4.800.000.000,00 (empat miliar delapan ratus juta rupiah) dalam 1 (satu) Tahun Pajak.

3. Tidak termasuk Wajib Pajak orang pribadi sebagaimana dimaksud pada ayat (2) adalah Wajib Pajak orang pribadi yang melakukan kegiatanusaha perdagangan dan/atau jasa yang dalam usahanya:

a. menggunakan sarana atau prasarana yang dapat dibongkar pasang, baik yang menetap maupun tidak menetap; dan 
b. menggunakan sebagian atau seluruh tempat untuk kepentingan umum yang tidak diperuntukkan bagi tempat usaha atau berjualan.

\section{Pajak Penghasilan}

Pajak penghasilan $(\mathrm{PPh})$ dikenakan terhadap Orang Pribadi dan Badan, berkenaan dengan penghasilan yang diterima atau diperoleh selama satu tahun pajak. Dalam undangundang nomor 7 tahun 1983, Subyek Pajak terbagi menjadi dua, yaitu Subyek Pajak Perseorangan atau Orang Pribadi dan Subyek Pajak Badan. Maka pajak yang akan dipungut dari kedua subyek pajak tersebut. Pemungutan tergantung kepada system pengenaan pajak yang dianut oleh masing-masing Negara.

Hipotesis adalah suatu penjelasan sementara tentang perilaku, fenomena, atau keadaan tertentu yang telah terjadi atau akan terjadi. Hipotesis merupakan pernyataan peneliti tentang hubungan antara variabel - variabel dalam penelitian, serta merupakan pernyataan yang paling spesifik (Indrianto Nur, Bambang Supomo 2010 : 189).

Hipotesis berupa pernyataan mengenai konsep yang dapat dinilai benar atau salah jika menunjuk pada suatu fenomena yang diamati atau diuji secara empiris. Berdasarkan teori diatas dapat disusun hipotesis penelitian sebagai berikut.

$\mathrm{H}_{0}$ : Dampak Pemahaman Wajib Pajak atas PP. Nomor 46 Tahun 2013 tidak berpengaruh Terhadap Penerimaan Pajak Penghasilan Pasal 21

$\mathrm{H}_{\mathrm{a}}$ : Dampak Pemahaman Wajib Pajak atas PP. Nomor 46 Tahun 2013 berpengaruh Terhadap Penerimaan Pajak Penghasilan Pasal 21

\section{METODE PENELITIAN}

\subsection{Data}

Jenis penelitian yang digunakan dalam penelitian ini adalah Asosiatif. Dimana penelitian ini bertujuan untuk menguji hipotesis asosiatif dengan menanyakan antar dua variabel atau lebih.

Penelitian ini berlokasi di Kotamobagu yaitu pada Kantor Pelayanan Pajak (KPP) Pratama Kotamobagu dan pada semua wajib pajak yang terdaftar di Kantor Pelayanan Pajak (KPP) Pratama Kotamobagu di wilayah Amurang dalam bentuk wawancara dan penyebaran angket atau kuisioner terstruktur yang telah disediakan sebelumnya untuk melakukan penelitian. Periode waktu penelitian selama bulan April.

Populasi adalah wilayah generalisasi yang terdiri atas obyek atau subyek yang mempunyai kualitas dan karakteristik tertentu yang ditetapkan oleh peneliti untuk dipelajari dan kemudian ditarik kesimpulannya. Jadi populasi bukan hanya orang, tetapi juga objek dan benda-benda alam yang lain. Populasi juga bukan sekedar jumlah yang ada pada obyek atau subyek yang dipelajari, tetapi meliputi seluruh karakteristik atau sifat yang dimiliki oleh subyek atau obyek itu. (Sugiyono,2013:117). Sedangkan sampel adalah sebagian dari jumlah dan karakteristik yang dimiliki oleh populasi tersebut (Sinambelan, 2014:95). Populasi dari penelitian ini adalah wajib pajak yang mempunyai peredaran bruto kurang dari Rp. 4,8 Milliar.Dan sampel dari penelitian ini berjumlah 63 wajib pajak sesuai data yang diperoleh dari hasil penelitian di KPP Pratama Kotamobagu.

\subsection{Metode Analisis}

Metode analisis yang dipakai dalam penelitian ini adalah uji validitas dan reliabilitas, uji asumsi klasik, metode regresi sederhana, analisis korelasi dan determinasi, uji F, uji t.

\section{HASIL ANALISIS DAN PEMBAHASAN 4.1 Hasil Analisis}

Kantor Pelayanan Pajak Pratama Kotamobagu (KPP PratamaKotamobagu) berdiri sejak tanggal 27 November 2008. Dan saat ini mulai beroperasi tanggal 1 Desember 2008 yang merupakan pecahan atau peleburan dari kantor Pelayanan Pajak Pratama Manado, 
kantor Pelayanan Pajak Bumi dan Bangunan Amurang, kantor Pemeriksaan dan Penyidikan Pajak Manado dan kantor Penyuluhan dan Pengamatan Perpajakan. Saat mulai operasi pertama Kantor Pelayanan Pajak Pratama Kotamobagu berkedudukan di jalan Bethesda Manado bekas kantor Pemeriksaan dan Penyidikan Pajak Manado dan pada bulan September 2010 KPP Pratama Kotamobagu pindah ke jalan yusuf hasiruni no. 39 kotobangun kotamobagu dan menempati bekas kantor penyuluhan dan pengamatan potensi perpajakan (KPA Kotamobagu).

\section{Uji Validitas dan Reliabilitas Data}

Validitas adalah ketepatan atau kecermatan suatu instrument dalam mengukur apa yang ingin diukur. Hasil uji validitas pada taraf signifikan 0,05 diperoleh dari pengolahan data SPSS 20.00 tampak pada tabel 4.4.

Tabel 4.4 Hasil Uji Validitas Variabel Pemahaman Wajib Pajak

\begin{tabular}{llll}
\hline No & Pearson Correlation & Signifikansi & Kriteria \\
\hline 1 & 0.666 & 0.000 & Valid \\
\hline 2 & 0.738 & 0.000 & Valid \\
\hline 3 & 0.600 & 0.000 & Valid \\
\hline 4 & 0.592 & 0.000 & Valid \\
\hline 5 & 0.612 & 0.000 & Valid
\end{tabular}

Sumber : Data Olahan, 2015

Tabel 4.5 Hasil Uji Validitas Variabel Penerimaan Pajak Penghasilan

\begin{tabular}{llll}
\hline No & Pearson Correlation & Signifikansi & Kriteria \\
\hline 1 & 0.640 & 0.000 & Valid \\
\hline 2 & 0.784 & 0.000 & Valid \\
\hline 3 & 0.584 & 0.000 & Valid \\
\hline 4 & 0.734 & 0.000 & Valid \\
\hline 5 & 0.643 & 0.000 & Valid \\
\hline
\end{tabular}

Sumber : Data Olahan, 2015

Dari hasil analisis dapat dilihat bahwa koefisien korelasi dari setiap item pertanyaan < 0.05.maka dapat dikatakan bahwa ada korelasi positif antara item pertanyaan masing-masing faktor dengan total itemnya. Dengan demikian instrument yang digunakan dalam penelitian ini adalah valid.

Tabel 4.6 Hasil Uji Reliabilitas

\begin{tabular}{llll}
\hline \multicolumn{2}{l}{ Variabel Pemahaman Wajib Pajak } & \multicolumn{2}{l}{ Variabel Penerimaan Pajak Penghasilan } \\
\hline Cronbach's Alpha & N of Items & Cronbach's Alpha & N of Items \\
\hline 0.624 & 5 & 0.795 & 5 \\
\hline
\end{tabular}

Sumber : Data Olahan, 2015 
Nampak dari tabel 4.6 variabel Pemahaman Wajib Pajak memiliki nilai Cronbach's Alpha sebesar $r=0.624$ dan variabel Penerimaan Pajak Penghasilan memiliki nilai Cronbach's Alpha sebesar $r=0.795$. Suatu instrument dapat dikatakan reliabel jika koefisien Cronbach's Alpha di atas 0.6, sehingga dapat dikatakan instrument mempunyai reliabilitas tinggi (Pramesti 2014 : 44)

\section{Hasil Pengujian Asumsi Klasik}

Pengujian asumsi klasik dilakukan untuk mengetahui apakah hubungan antara variabel bebas dan variabel terikat.Berdasarkan hasil pwngolahan data yang menggunakan program aplikasi SPSS versi 20.0 maka diperoleh interpretasi dari hasil pengujian asumsi klasik sebagai berikut.

Uji Normalitas

Persamaan regresi yang baik memiliki distribusi variabel-variabel yang normal atau mendekati normal. Hasil pengujian normalitas dengan menggunakan pendekatan grafik Normal P-P Plot Of Regression Standardized Residual dan mengikuti arah diagonal tersebut, maka model regresi memenuhi asumsi normalitas.

Gambar 4.2 Grafik Normal Q-Q Plot Of Total

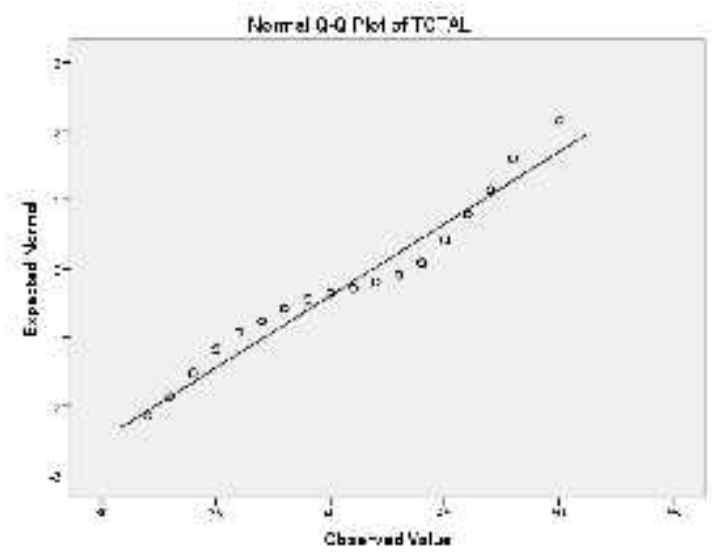

Sumber : Data Olahan, 2015

Pada gambar 4.2 , Normal P-P Plot, data pada penerimaan pajak penghasilan pasal 21 dinyatakan terdistribusi normal karena gambar distribusi dengan titik-titik data yang menyebar disekitar garis diagonal dan penyebaran titik-titik data searah mengikuti garis diagonal.

Uji Heteroskedastisitas

Untuk mendeteksi ada tidaknya heteroskedastisitas dalam penelitian ini, dapat dilihat melalui analisis grafik Scatterplot pada gambar 4.3. Dari grafik Scatterplot pada gambar 4.3 terlihat bahwa titik-titik cukup menyebar di atas dan di bawah angka 0 (nol), sehingga dapat disimpulkan bahwa tidak terjadi heteroskedastisitas pada model regresi dalam penelitian ini. 
Gambar 4.3 Hasil Uji Heteroskedastisitas

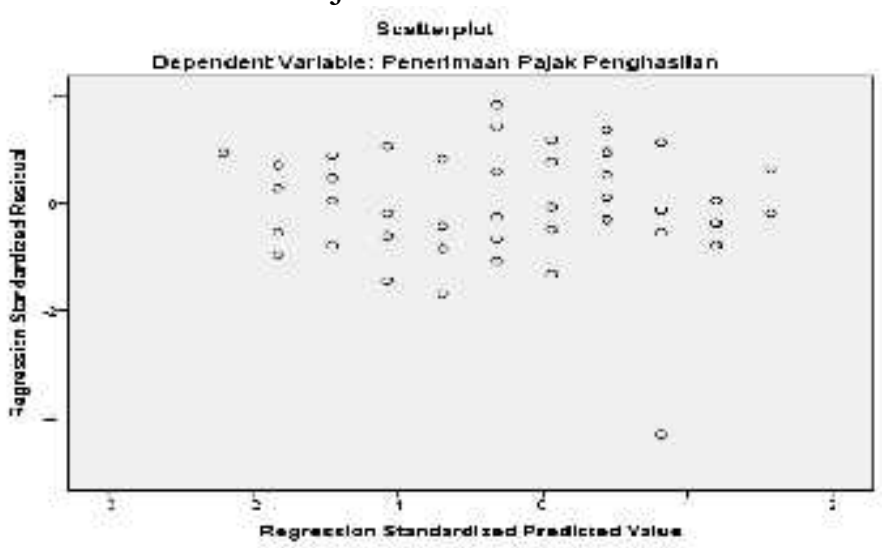

Sumber : Data Olahan, 2015

Setelah dilakukan beberapa pengujian asumsi klasik, yaitu uji normalitas dan uji heteroskedastisitas, maka terbukti bahwa hasil analisa regresi dalam penelitian ini telah bebas dari gangguan normalitas dan heteroskedastisitas.

\section{Hasil Regresi Linier}

Regresi Sederhana

Hasil analisis regresi linier sederhana yang diperoleh dari pengolahan data menggunakan SPSS 20.0 tampak pada Tabel 4.7. Berdasarkan Tabel 4.7, maka menghasilkan:

$$
\begin{aligned}
& Y^{\prime}=a+b X \\
& Y^{\prime}=9.157+0.571 X \\
& \text { Keterangan : } \\
& X=\text { variabel pemahaman wajib pajak } \\
& Y=\text { variabel penerimaan pajak penghasilan pasal } 21 \\
& a, b=\text { koefisien korelasi }
\end{aligned}
$$

\begin{tabular}{|c|c|c|c|}
\hline \multirow{2}{*}{ Model } & Unstandardized Coefficients & \multirow[t]{2}{*}{$\mathrm{T}$} & \multirow[t]{2}{*}{ Sig. } \\
\hline & $\mathrm{B}$ & & \\
\hline 1 (Constant) & 9.157 & 3.801 & .000 \\
\hline Pemahaman & .571 & 4.982 & .000 \\
\hline
\end{tabular}

Tabel 4.7 Hasil Uji Regresi Sederhana

a. Dependent variable: PenerimaanPajakPenghasilan

Sumber : Data Olahan, 2015

Berdasarkan persamaan regresi linier sederhana, dapat dilihat nilai konstanta (a) sebesar 9.157.hal ini berarti apabila variabel pemahaman wajib pajak sama dengan $=0$ maka besarnya penerimaan pajak penghasilan (Y) sebesar 9.157 satuan. Koefisien regresi Pemahaman wajib pajak (X) sebesar 0,571 menunjukkan bahwa setiap adanya peningkatan pemahaman wajib pajak sebesar 1 satuan skor, maka akan mengakibatkan peningkatan penerimaan pajak penghasilan (Y) sebesar 0,571 satuan skor.

Korelasi (R)

Hasil koefisien korelasi linier yang diperoleh dari pengolahan data menggunakan SPSS 20.0 tampak pada Tabel 4.8 . Berdasarkan Tabel 4.8, maka model persamaan korelasi linier dalam penelitian ini adalah sebagai berikut. 
Tabel 4.8 Hasil Uji Korelasi (R)

\begin{tabular}{lll}
\hline Model & $\mathrm{R}$ & R Square \\
\hline 1 & $.541^{\mathrm{a}}$ & .293 \\
\hline
\end{tabular}

a. Predictors: (Constant), Pemahaman Wajib Pajak

b. DependentVariable: Penerimaan Pajak Penghasilan

Sumber : Data Olahan, 2015

Bahwa antara pemahaman wajib pajak (X) dengan penerimaan pajak penghasilan ( $\mathrm{Y}$ ) adalah 0,541 artinya pemahaman wajib pajak memiliki hubungan yang cukup kuat yaitu sebesar 0,541 .

Hasil perhitungan koefisien determinasi dalam penelitian ini tampak bahwa nilai koefisien determinasi adalah 0,293. Hal ini menunjukkan bahwa besarnya pengaruh variabel bebas, yaitu pemahaman wajib pajak terhadap variabel terikat yaitu penerimaan pajak penghasilan yang diterangkan oleh model persamaan dalam penelitian ini adalah sebesar $29,3 \%$, sedangkan sisanya sebesar $70,7 \%$ diterangkan oleh faktor-faktor lain yang tidak dimasukkan dalam model regresi.

\section{Hasil Pengujian Hipotesis}

Hasil uji t (Uji Regresi Sederhana). Uji ini digunakan untuk mengetahui apakah variabel independen (X) berpengaruh signifikan terhadap variabel (Y). Untuk hasil uji t (uji regresi sederhana) dapat dilihat pada Tabel 4.9.

Tabel 4.9 Hasil Uji t

\begin{tabular}{lll}
\hline Model & T & Sig. \\
\hline 1 (Constant) & 3.801 & .000 \\
Pemahaman & 4.982 & .000
\end{tabular}

a. Dependent Variable: Penerimaan Pajak Penghasilan

Sumber : Data Olahan, 2015

Berdasarkan hasil regresi linier sederhana (uji t) pada tabel 4.9 diketahui nilai $t_{\text {hitung }}>t_{\text {tabel }}$ (4.982>2.000) dan tingkat signifikan sebesar $0,00<0,05$. Maka hal ini menunjukkan bahwa Ho ditolak dan Ha diterima atau variabel pemahaman wajib pajak berpengaruh terhadap penerimaan pajak penghasilan di KPP Pratama Kotamobagu.

\subsection{Pembahasan}

Berdasarkan hasil diatas, maka dilihat bahwa terdapat pengaruh antara variabel bebas $\mathrm{X}$ (pemahaman wajib pajak) terhadap variabel terikat $\mathrm{Y}$ (penerimaan pajak penghasilan). Pada penelitian ini didapatkan hasil uji $\mathrm{t}$ antara variabel bebas pemahaman wajib pajak (X) terhadap variabel terikat penerimaan pajak penghasilan (Y) dilihat pada tabel 4.6. Diperoleh $t_{\text {hitung }}>t_{\text {tabel }}$ maka Ho ditolak dan $\mathrm{Ha}$ diterima. Hal ini menunjukkan bahwa variabel pemahaman wajib pajak berpengaruh terhadap penerimaan pajak penghasilan pada KPP Pratama Kotamobagu. Hal ini berarti, apabila pemahaman wajib pajak meningkat, maka penerimaan pajak penghasilan juga akan mengalami peningkatan. Hal ini ditunjang dengan penelitian penulis dimana penerimaan pajak penghasilan pasal 21 pada KPP Pratama Kotamobagu terus mengalami peningkatan.

Koefisien korelasi yang dihasilkan berdasarkan penelitian yang ada antara pemahaman wajib pajak $(\mathrm{X})$ dengan penerimaan pajak penghasilan $(\mathrm{Y})$ memiliki hubungan yang searah sehingga berdampak positif terhadap penerimaan pajak penghasilan dan berarti semakin 
banyak penerimaan pajak yang bisa digunakan dalam pembangunan nasional negara kita ini yang dapat kita nikmati bersama.

Koefisien determinasi menunjukkan bahwa besarnya pengaruh pemahaman wajib pajak atas PP No. 46 Tahun 2013 (X) terhadap penerimaan pajak penghasilan (Y) sebesar 29,3\%, sedangkan sisanya sebesar 70,7\% diterangkan oleh faktor-faktor lain yang tidak diteliti dalam penelitian ini misalnya jumlah wajib pajak, kepatuhan wajib pajak, sosialisasi perpajakan, pemeriksaan pajak, kesadaran wajib pajak.

Penerimaan PPh Pasal 21 Pada KPP Pratama Kotamobagu

Tabel 4.10 Penerimaan Pajak Penghasilan Pasal 21

\begin{tabular}{llll}
\hline & \multicolumn{1}{c}{2010} & \multicolumn{1}{l}{2011} & \multicolumn{1}{l}{2012} \\
\hline OP & 246.921 .606 & 255.266 .852 & 407.411 .079 \\
BADAN & \multicolumn{1}{c}{8.808 .474 .541} & 11.758 .671 .396 & 15.128 .449 .936 \\
& 2013 & 2014 & 2015 \\
OP & 197.589 .039 & 18.389 .626 .715 & 10.043 .835 \\
BADAN & 15.953 .736 .621 & 91.643 .566 & 8.901 .163 .335 \\
\hline
\end{tabular}

Sumber : KPP Pratama Kotamobagu

Dari tabel 4.10 kita bisa melihat bahwa penerimaan Pajak Penghasilan Pasal 21 pada KPP Pratama Kotamobagu yang di bayarkan oleh orang pribadi (OP) dari tahun 2010 sampai bulan mare 2015 terus mengalami peningkatan. Ini merupakan bukti bahwa pemahaman wajib pajak akan ketentuan perpajakan serta peraturan pajak yang ada mengalami kemajuan yang mendorong wajib pajak untuk terus menyetorkan kewajiban perpajakan mereka. Dan ini semua tidak terlepas dari peranan pemerintah begitu juga dengan petugas-petugas dari tiaptiap KPP dan KP2KP yang terus mensosialisasikan tentang peraturan perpajakan yang ada serta cara dan prosedur membayar pajak sehingga membuat wajib pajak lebih mengerti dan memahami cara membayar pajak dengan baik serta prosedur administrasi dan pelayanan dari tiap-tiap Kantor Pelayanan Pajak (KPP) yang begitu baik sehingga membuat wajib pajak nyaman dalam menyetorkan kewajiban perpajakannya.

\section{KESIMPULAN}

Berdasarkan hasil penelitian dan pembahasan yang telah dikemukakan sebelumnya, maka dapat di ambil kesimpulan sebagai berikut. Penelitian ini menerima hipotesis kedua $\left(\mathrm{H}_{\mathrm{a}}\right)$, yaitu bahwa pemahaman wajib pajak atas PP No. 46 Tahun 2013 berpengaruh terhadap penerimaan pajak penghasilan pasal 21 (PPh Pasal 21).Berdasarkan hasil uji t antara variabel bebas pemahaman wajib pajak (X) terhadap variabel terikat penerimaan pajak penghasilan (Y) diperoleh $t_{\text {hitung }}>t_{\text {tabel }}$. Maka Ho ditolak dan Ha diterima. Hal ini menunjukkan bahwa variabel pemahaman wajib pajak berpengaruh terhadap penerimaan pajak penghasilan di KPP Pratama Kotamobagu. Hal ini berarti, apabila pemahaman wajib pajak meningkat, maka penerimaan pajak penghasilan juga akan mengalami peningkatan. Dari hasil uji regresi linier sederhana menunjukkan bahwa pemahaman wajib pajak atas PP No. 46 Tahun 2013 memiliki pengaruh yang cukup besar terhadap penerimaan pajak penghasilan ( $\mathrm{PPh}$ Pasal 21) pada KPP Pratama Kotamobagu.

Adapun saran yang dapat diberikan oleh penulis setelah melakukan penelitian ini adalah sebagai berikut.Pemahaman wajib pajak atas peraturan-peraturan perpajakan yang ada dapat diperoleh melalui sosialisasi dan penyuluhan yang baik dari petugas KPP maupun KP2KP. Untuk itu disarakan untuk lebih ditingkatkan lagi sosialisasi dan penyuluhan tentang peraturan-peraturan perpajakan, upaya penegakkan hukum mengenai sanksi, denda, tariff, maupun hal lainnya yang perlu diketahui oleh wajib pajak agar bisa memahami dan mau menyetorkan kewajiban perpajakannya. Diharapkan pula dapat dilaksanakan dengan gratis 
dan senyaman mungkin agar wajib pajak tidak terbeban dan tidak bosan dalam mengikutinya. Dengan adanya pemahaman yang baik dari wajib tentang peraturan-peraturan perpajakan, upaya penegakkan hukum mengenai sanksi, denda, tarif, wajib pajak mau menyetorkan kewajiban perpajakannya. Agar penerimaan pajak lebih meningkat dengan demikian pembangunan di negara ini lebih baik untuk kedepannya. Sebagai bahan masukan untuk penelitian berikutnya dapat mengkaji variabel dependen lain yang juga dapat memengaruhi penerimaan pajak penghasilan.

\section{DAFTAR PUSTAKA}

Arikunto (2009), Dasar-dasar Evaluasi Pendidikan, Edisi Revisi, PT. Bumi Aksara, Jakarta Devano, Sony dan Siti Kurnia Rahayu , (2008), Perpajakan Konsep, Teori, dan Isu kenana, Jakarta.

Eunike jaclin Susilo (2014), Pemahaman wajib pajak terhadap PP No. 46 Tahun 2013 tentang pajak UMKM (studi kasus pada wajib pajak yang terdaftar di Kantor Pelayanan Pajak Pratama Palembang Lir Barat), Sekolah Tinggi Imu Ekonomi Multi Data Palembang. Dari : eprints.mdp.ac.id/1134/id.m.wikipedia.org/wiki/Kota_Kotamobagu id.m.wikipedia.org/wiki/Pajak_penghasilan

Ilyas, Richard Butrton. (2011), HukumPajak,Edisi 5-Cetakan kedua,SalembaEmpat,Jakarta. Indriantoro dan Supomo. (2009) Metodologi Penelitian Bisnis Untuk Akuntansi Dan Manajemen. Edisi pertama cetakan ke - 3, BPFE, Yogyakarta. Mardiasmo (2011), Perpajakan, Edisi Revisi, Andi, Yogyakarta.

Nashrudin Elia Mustika Sari (2014), Pengaruh Persepsi Atas PP Nomor 46 Tahun 2013 Terhadap Kepatuhan Sukarela Wajib Pajak Yang Memiliki Peredaran Bruto Tertentu Pada Kantor Pelayanan Pajak Pratama Surabaya Rungkut, Universitas Airlangga. Dari : multiparadigma.lecture.ub.ac.id/files/2014/09/094.pdf

Pramesti. (2014), Kupas Tuntas Data Penelitian dengan SPSS 22, PT. Elex Media Komputindo, Jakarta.

Purwono. (2010), Dasar-Dasar Perpajakan dan Akuntansi Pajak, Erlangga. Resmi (2009), Perpajakan: Teori dan Kasus, Edisi 5 - buku 1, Salemba Empat, Jakarta.

Saeh. (2011). Pengaruh Pelaksanaan Penganggaran Berbasis Kinerja Terhadap Efektivitas Pengendalian Manajemen Di Pemerintah Kota Manado, Skripsi, FakultasEkonomi Dan BisnisUniversitas Sam Ratulangi Manado.

Sinambelan (2014), Metodologi Penelitian Kuantitatif; Untuk Bidang Ilmu Administrasi,Kebijakan Publik, Ekonomi, Bisnis, Komunikasi dan Ilmu Sosial Lainnya, Grahallmu, Yogyakarta.

Sumarsan, Thomas. (2012). Perpajakakan Indonesia, PT. Index. Jakarta. Sunyonto, Danang. (2008). Analisa regresi dan uji hipotesis. PT. Buku Kita, Yogyakarta Waluyo .(2013). Perpajakan Indonesia,Edisi 11 - buku 1, Salemba Empat, Jakarta. 